\title{
THE SPREAD OF THE NEOLITHIC IN THE SOUTH EAST EUROPEAN PLAIN: RADIOCARBON CHRONOLOGY, SUBSISTENCE, AND ENVIRONMENT
}

\author{
Pavel M Dolukhanov ${ }^{1} \bullet$ Anvar Shukurov $^{2} \cdot$ Kate Davison $^{2} \bullet$ Graeme Sarson $^{2} \bullet$ Natalia P \\ Gerasimenko $^{3}$ - Galina A Pashkevich ${ }^{4} \cdot$ Aleksandr A Vybornov $^{5} \cdot$ Nikolai N Kovalyukh $^{6} \bullet$ \\ V V Skripkin ${ }^{6}$ Ganna I Zaitseva ${ }^{7} \cdot$ Tatiana V Sapelko $^{8}$
}

\begin{abstract}
Newly available radiocarbon dates show the early signs of pottery-making in the North Caspian area, the Middle-Lower Volga, and the Lower Don at 8-7 kyr cal BC. Stable settlements, as indicated by "coeval subsamples," are recognized in the Middle-Lower Volga (Yelshanian) at $6.8 \mathrm{kyr}$ cal BC and the Caspian Lowland at about $6 \mathrm{kyr}$ cal BC. The ages of the Strumel-Gostyatin, Surskian, and Bug-Dniesterian sites are in the range of 6.6-4.5 kyr BC, overlapping with early farming entities (Starčevo-Körös-Criș and Linear Pottery), whose influence is perceptible in archaeological materials. Likewise, the ${ }^{14} \mathrm{C}$-dated pollen data show that the spread of early pottery-making coincided with increased precipitation throughout the forest-steppe area.
\end{abstract}

\section{INTRODUCTION}

Recently available radiocarbon dates show that the early pottery-making communities in the steppe and boreal areas of eastern Europe started spreading at an early date, comparable to and even preceding in age to the early farming communities in southeastern Europe. In most of these cases, the subsistence pattern remained essentially Mesolithic with little or no evidence of farming or stockbreeding. Yet the appearance of pottery-making signaled the appearance of attributes of complex societies, such as sedentism, increased population density, intensive food procurement, technological innovations, development of exchange networks (which in some cases included their agricultural neighbors), social differentiation, and territorial control. Consequently, the current project, among other objectives, was focused on: (1) improved ${ }^{14} \mathrm{C}$-based and statistically tested chronologies of early pottery sites in the south East European Plain; (2) detailed assessment of the environments of early pottery-making sites; and (3) developing a mathematically robust model of the transition to the Neolithic using the aforementioned data.

\section{METHODS}

We use ${ }^{14} \mathrm{C}$ data sets for the early Neolithic cultures of the southern steppe zone of eastern Europe (Figure 1). Some of the dates (for the Bug-Dniesterian, Surskian, Dnieper-Donietz, Azov-Dnieperian, and Donetsian cultures) have been published by Kotova $(2002,2003)$, whereas newly obtained dates (for the Yelshanian, North Caspian, Rakushechyj Yar, and Strumel-Gastyatin cultures) are published in Dolukhanov et al. (2009). All ${ }^{14} \mathrm{C}$ dates discussed here are presented as calibrated BC (cal BC). However, the ages obtained from statistical modeling are given in yr BC; any modeling was applied to calibrated ${ }^{14} \mathrm{C}$ dates. OxCal v. 4.0 (Bronk Ramsey 1995, 2001) with the calibration curve IntCal04 (Reimer et al. 2004) was used for the calibration. Uncertainty of the individual cali-

\footnotetext{
${ }^{1}$ School of Historical Studies, Newcastle University, Newcastle upon Tyne, United Kingdom. Corresponding author. Email: pavel.dolukhanov@ncl.ac.uk.

${ }^{2}$ School of Mathematics and Statistics, Newcastle University, Newcastle upon Tyne, United Kingdom.

${ }^{3}$ Department of Earth Sciences and Geomorphology, Taras Shevchenko National University, Kiev, Ukraine.

${ }^{4}$ Institute of Archaeology, National Academy of Sciences, Kiev, Ukraine.

${ }^{5}$ Samara Pedagogical University, Russia.

${ }^{6}$ Radiocarbon Laboratory, Institute of Environmental Geochemistry, National Academy of Sciences, Kiev, Ukraine.

${ }^{7}$ Radiocarbon Laboratory, Institute for History of Material Culture, Russian Academy of Sciences, St. Petersburg, Russia.

${ }^{8}$ Institute of Limnology, Russian Academy of Sciences, St. Petersburg, Russia.
}

(C) 2009 by the Arizona Board of Regents on behalf of the University of Arizona

Proceedings of the 5th International ${ }^{14} \mathrm{C}$ and Archaeology Symposium, edited by Irka Hajdas et al.

RADIOCARBON, Vol 51, Nr 2, 2009, p 783-793 
brated dates was characterized by the corresponding fraction (1/4 or $1 / 6)$ of the continuous calibrated date interval at the confidence levels $95.4 \%$ and $99.7 \%$ (the latter was used if the former interval had significant discontinuities).

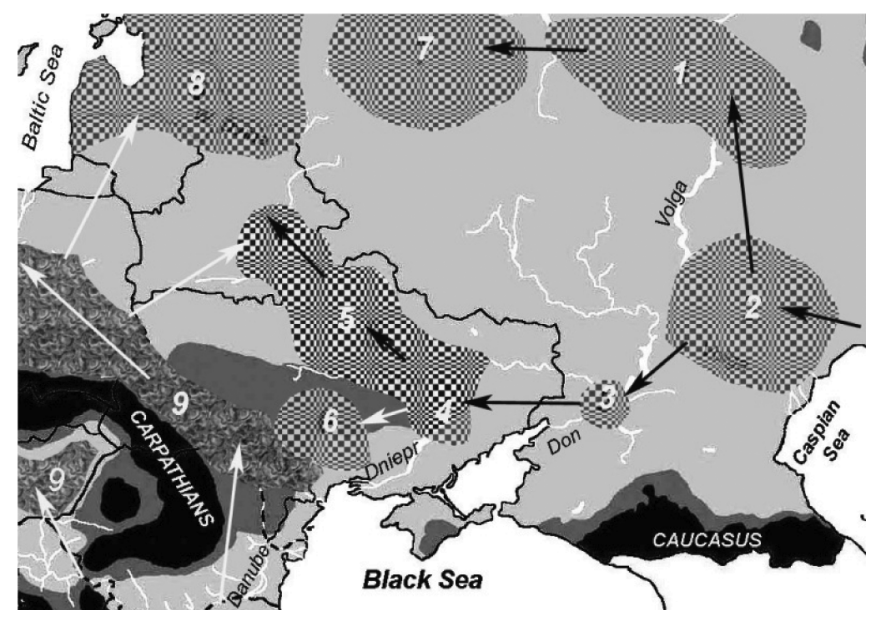

Figure 1 Early Neolithic cultures in eastern and central Europe: 1-Yelshanian; 2-North Caspian; 3-Rakushechnyj Yar; 4-Surskian; 5-Dnieper-Donetsian; 6Bug-Dniesterian; 7-Upper Volga; 8-Narvian; 9-Linear Pottery. White arrows: expansion of early farming; black arrows: spread of pottery-making traditions.

The ${ }^{14} \mathrm{C}$ dates used here have been obtained for the organic matter in the pottery, animal and human bones, and freshwater mollusk shells found in the archaeological deposits. Human bones and mollusk shell are affected by the ${ }^{14} \mathrm{C}$ reservoir effect, which offsets the dates towards older ages (Lillie et al. 2008; Zaitseva et al. 2009). This effect is as yet difficult to quantify in general terms, so we treat such dates at their face value here. The entities most strongly affected by this effect are the Dnieper-Donets and Azov-Dnieperian cultures, where most of the dates come from cemetery skeletal remains; the age estimates for these cultures should be treated with caution. A significant number of dates for the Yelshanian culture used here are from mollusk shells, but they do not belong to the oldest group of dates and thus do not affect our conclusions.

The data sets used in this paper contain a statistically significant number of ${ }^{14} \mathrm{C}$ dates for each of the cultures, which justifies our attempt to apply statistical modeling to them. It is a widely recognized problem that choosing the oldest date from a set of multiple date determinations, in order to characterize a "first arrival" event, can amount to choosing the least probable date from the set. More sophisticated procedures are required, but there are no universally adopted procedures of this kind. The approach used in this paper is detailed below (see Davison et al. 2009 for a detailed discussion).

If only a few $(<8)$ date measurements are available, and those dates all agree within the error, we use their weighted mean value. For a series of dates that cluster in time but do not agree within the calibration error, we use different approaches depending on the number of dates available and their errors. Should the cluster contain $<8$ dates, we take the mean of the dates (as in the previous case), as any more sophisticated statistical technique would be inappropriate for such a small sample. If, however, the date cluster is large (i.e. $>8$ dates), the $\chi^{2}$ statistical test can be used to calculate the most likely date $T_{0}$ of a coeval subsample as described in detail by Dolukhanov et al. (2005). The calculations results are presented in the form $T=T_{0} \pm \Delta$, where $\Delta$ is the confidence interval corresponding to the $1-\sigma$ deviation. The uncertainty of the resulting age estimate is then characterized by 
the standard deviation of the dates in the coeval subsample, denoted $\sigma_{\mathrm{c}}$. Our procedure is very similar to that implemented in the "R_Combine" function of OxCal (Bronk Ramsey 2001). However, OxCal's procedure first combines the uncalibrated dates into a single ${ }^{14} \mathrm{C}$ measurement and only then calibrates it. Our approach, on the other hand, first uses the calibration scheme of OxCal and then combines the resulting calibrated dates to give $T$. For our purposes, this adds the flexibility of discarding dates with the largest relative deviation from $T$. As a check, we combined several sets of dates using both OxCal and our procedure; the results agree within an acceptable margin.

If a geographically localized culture has many ${ }^{14} \mathrm{C}$ determinations that do not cluster around a single date, a histogram of the dates is analyzed. If the data have a wide range and have no discernible peaks (i.e. are approximately uniformly distributed in time), they may suggest prolonged Neolithic activity at the site, and we choose, as many other authors, the oldest date (or one of the oldest, if there are reasons to reject outliers) to identify the first appearance of the Neolithic. Apart from sites with either no significant peak or only 1 peak, there are sites whose ${ }^{14} \mathrm{C}$ dates have a multimodal structure, which may indicate multiple waves of settlement passing through this location (e.g. the Yelshanian culture). In such cases, multiple dates were attributed to the culture.

\section{RESULTS}

\section{Environments}

Several ${ }^{14} \mathrm{C}$-dated pollen sequences are now available for the steppe and forest-steppe of Ukraine, notably, Glubokoe and Rogalik 12 (Figure 2) (Gerasimenko 1995). Based on this and other evidence, the reconstruction of the vegetation cover for Ukraine's Atlantic period was carried out. These data show the general expansion of mixed forests with broad-leaved species, oak, lime, elm, as well as hygrophilous elements, ash tree (Fraxinus excelsior) and ivy (Hedera helix), in a time span broadly coincident with the appearance of Neolithic settlements. The early Atlantic pollen spectra in the southwestern steppe (Beloles'e and Mirnoe sequences; Pashkevich 1982) show higher values of pine and broad-leaved arboreal species (Quercus, Tilia, Carpinus, Ulmus), the grassland dominated by forbs, and that Compositae and Chenopodiaceae acquired a mesophytic character. A similar character of Early Atlantic vegetation is evident in the Lower Dniester area (Volontir 1989). During the Atlantic period, forests expanded both northwards and southwards with respect to their present-day locations. Entire valleys of the Dnieper, Dniester, Southern Bug, Seversky Donets, and Don were forested, and the forests reached the Black Sea shores. Broad-leaved forests transgressed into the steppe, considerably diminishing the treeless area.

Recently obtained pollen evidence shows similar changes occurring in the eastern forest-steppe area. The sequence of the Chekalino I site on Sok River (a tributary of the Middle Volga, Samara Oblast) indicates the appearance of Ulmus, Quercus, and Populus pollen at the level of early Neolithic settlement (Figure 3, zone 2), suggesting the occurrence of floodplain forests. The high percentage of Chenopodiaceae, Artemisia, and Gramineae pollen signals the prevalence of steppe communities further afield.

According to quantitative estimates for various areas of the East European Plain (Khotinsky 1977, 1987; Kremenetsky 1991, 2003; Khotinsky and Klimanov 2002), the climate during the time span of about 6000-4500 BP was of a less continental character with milder winters and a mean annual temperature exceeding the present one by $2{ }^{\circ} \mathrm{C}$. In the steppe, the January temperature was higher than now by $1{ }^{\circ} \mathrm{C}$, and the July one, lower by $2^{\circ} \mathrm{C}$. Annual precipitation was higher by $100-150 \mathrm{~mm}$ (Kremenetsky 2003). The data for the Samara Oblast suggest increased precipitation and a lowering of temperature during the Atlantic period. 


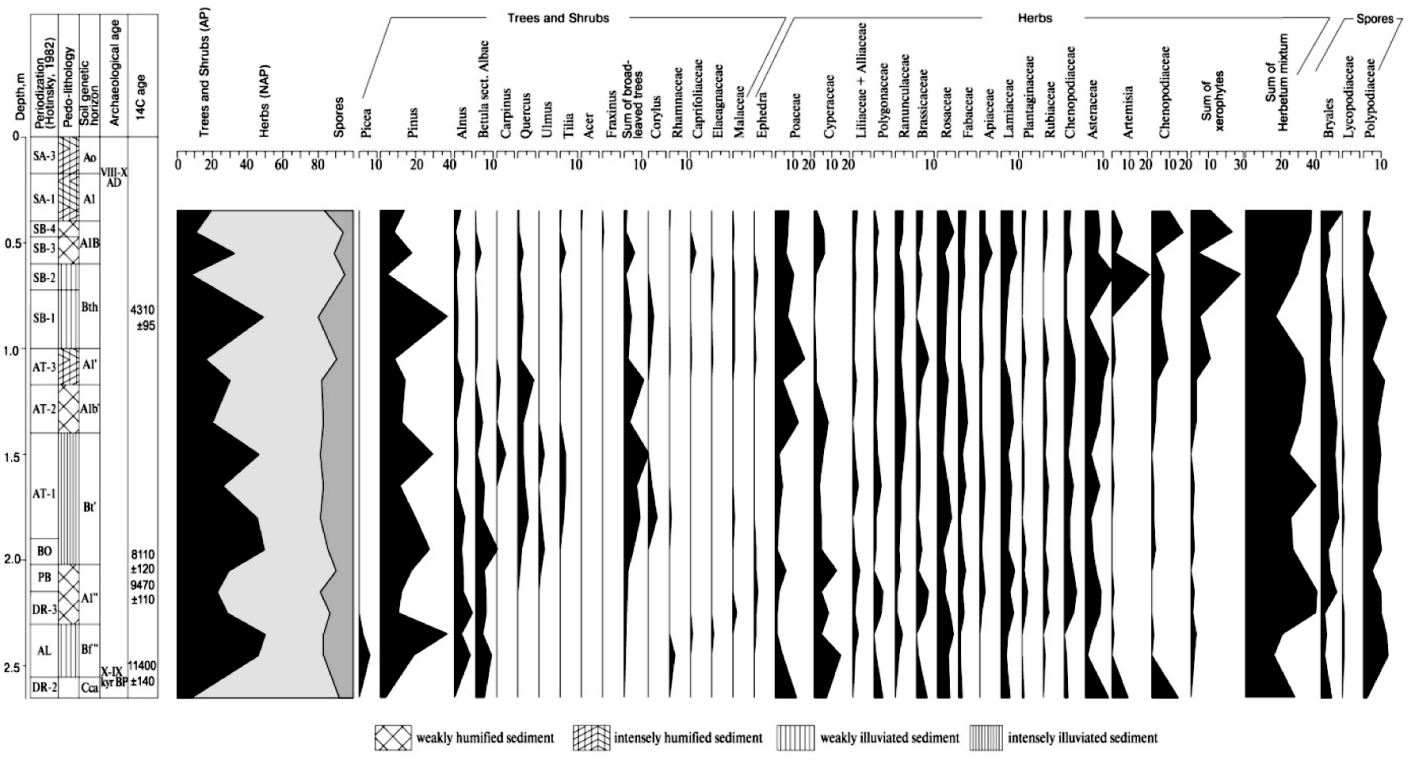

Figure 2 Pollen diagram of the Rogalik 12 peat bog

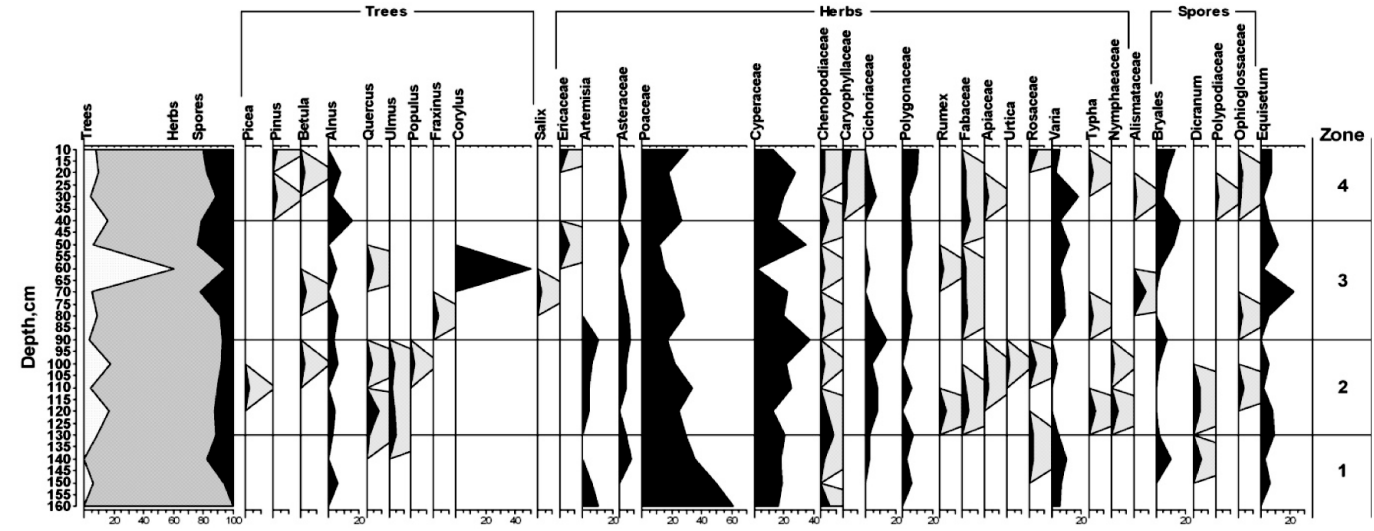

Figure 3 Pollen diagram of the Chekalino 4 site

\section{Chronology of Archaeological Sites}

\section{Yelshanian}

The Yelshanian-type (Y) pottery, the earliest technology of this kind on the East European Plain, was first recognized in the Samara-Volga area in the 1970s (Vasiliev and Panin 1977). By now, the typical "Yelshanian assemblage" has been identified at several sites: Staraya Yelshanka I, II; Maksimovo; Chekalino; Lower Orlyanka; Ivanovka; Lugovoye III; Lebyazh'ye I; Bol'she-Rakopvskaya; Il'ynskaya; Krasnyi Gorodok; Zakhar-Kolma; Vilovatovskaya; and a few others (Mamonov 1994; Lastovsky 2006). In all these sites, the "pure Yelshanian element" has been recognized only in 2 cases, the lower strata of Chekalino IV and Lower Orlyanka II.

Yelshanian pottery was manufactured from the local sandy clay, which included a natural admixture of organic matter and small fragments of mollusk shells. The vessels were fired in open hearths at 
temperatures not exceeding $450{ }^{\circ} \mathrm{C}$. The vessels had rounded or pointed bottoms and straight rims with either flat, round, or pointed edges, transforming into S-profiled rims. The majority of pottery vessels were not ornamented; in rare cases, one notes incised lines, pit impressions, or short notches, forming zigzag patterns. Several vessels were decorated by a belt beneath the rim consisting of pits and "pearl" impressions.

Presently, $22{ }^{14} \mathrm{C}$ dates have been obtained for the organic matter in the pottery and freshwater shells found in the archaeological deposits. These and other data have been processed in an attempt to identify the coeval periods. This test for the Yelshanian culture yields $T=6771 \pm 160 \mathrm{BC}$ with $\sigma_{\mathrm{c}}=$ $132 \mathrm{yr}$ (Figure 4a).

\section{The North Caspian}

Early pottery sites have been identified in various parts of the North Caspian (NC) Lowland and along the lower stretches of the Volga River. Vasiliev and Vybornov (1988) distinguish 2 cultural groups, the Kairshak-Tenteksorian and Jangar-Varfolomeyvian, which together form the Lower Volga cultural entity. Each group comprises several chronological stages. The Kasirshak-Tenteksorian culture had apparently developed on the local Mesolithic substratum, which is evident in the Mesolithic character of its lithic industry. Its pottery, which has no direct analogies, was manufactured from clay that included crushed shells, fish scales and vertebra, and plant remains. The pottery consists of straight-walled vessels with round bases, ornamented by incised lines and oval impressions forming simple geometric patterns.

The sites belonging to the Jangar-Varfolomeyevian cultural entity are found both on the right and left banks of the Volga River (Yudin 2004). Its common features include the prevalence of the blade technique in the stone inventory, with a high proportion of tools, particularly various types of endscrapers, with the common occurrence of geometrics and arrowheads. The pottery was usually manufactured from clay with crushed shells. The flat-based pots with strait or S-shaped walls were decorated in the upper portions by strokes and incised lines forming simple geometric patterns.

Recently, a large series of ${ }^{14} \mathrm{C}$ dates has been obtained for organic matter in the ceramics. The coeval sample test reveals $T=5859 \pm 236 \mathrm{yr} \mathrm{BC}$ with $\sigma_{\mathrm{c}}=192$. Significantly, there is a considerable number of dates falling beyond the subsample and showing ages in the range 8000-6500 BC (Figure 4b).

\section{Rakushechnyi Yar}

Rakushechnyi Yar (RY) is a clearly stratified settlement located on a small island in the lower stretches of the Don River (Belanovskaya 1995). The excavations exposed an area of $\sim 1200 \mathrm{~m}^{2}$, with 23 archaeological layers ranging from the Bronze Age to the Neolithic. The deepest levels (236) belong to the Early Neolithic. The pottery, which constitutes the main element of the material culture, is encountered in large quantities starting with the lowermost level of the site. These are straight-walled or slightly profiled flat- and conic-bottomed vessels with either straight or outside bended rims. In the ornamented vessels, the decoration was usually restricted to the upper portion and consists of impressions of stamps, fish bones, and shell rims. The coeval sample assessment of ${ }^{14} \mathrm{C}$ dates for Early Neolithic levels of RY yields $T=5960 \pm 260$ with $\sigma_{\mathrm{c}}=212$. As in the previous case, a significant number of older dates (6900-6600 BC) fall beyond the coeval sample (Figure 4c).

\section{Bug-Dniesterian}

The Early Neolithic in western Ukraine and Moldova is usually associated with sites of the BugDniesterian culture (BD) (Danilenko 1969; Markevich 1974). About 40 sites belonging to this cul- 


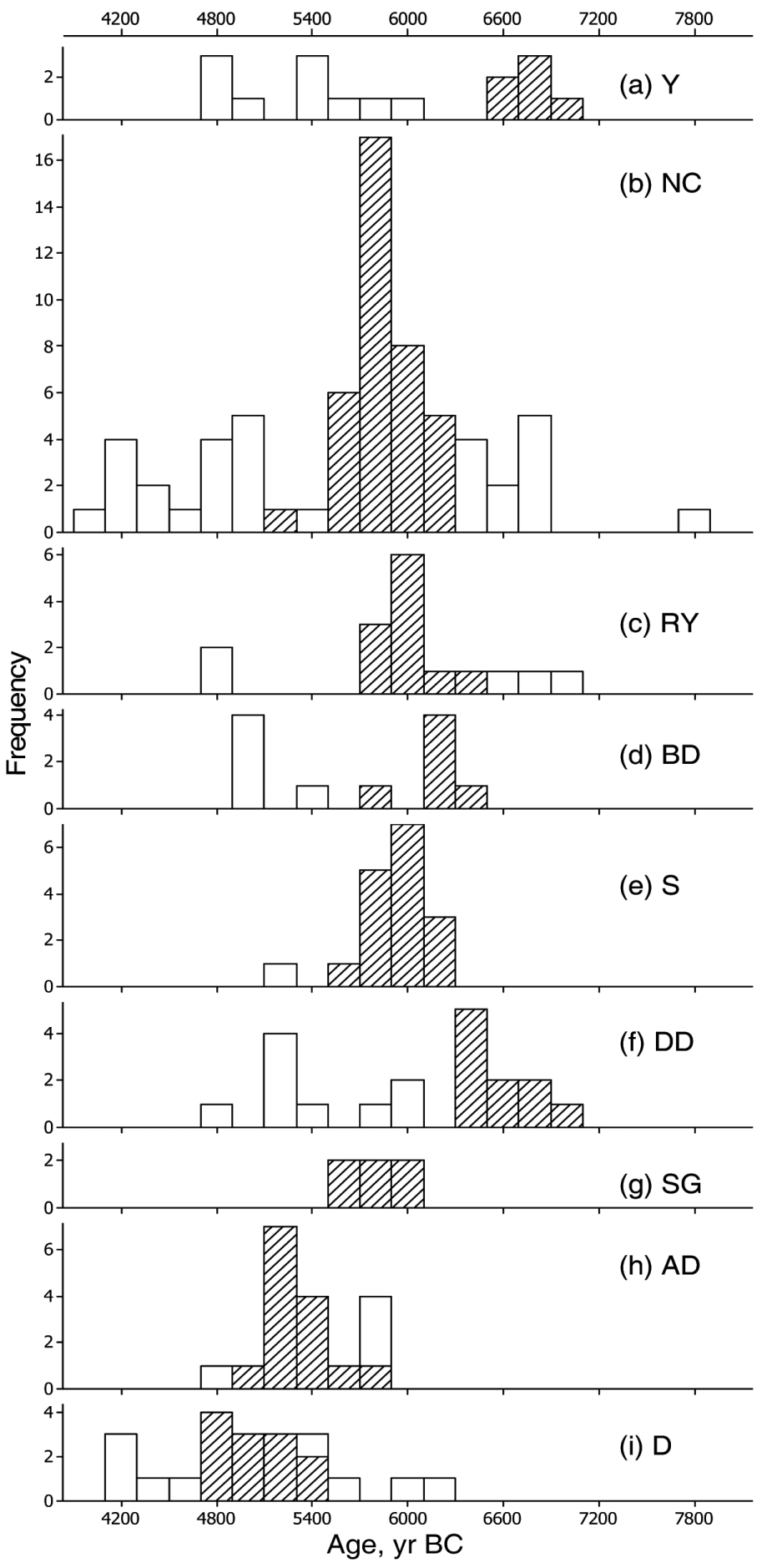

Figure 4 Frequencies of ${ }^{14} \mathrm{C}$ dates (coeval samples hatched): $\mathrm{a}-$ Yelshanian; $\mathrm{b}-$ North Caspian; c-Rakushechnyi Yar; d-Bug-Dniesterian; e-Surskian; f-DnieperDonetsian; g-Strumel-Gostyatin; h-Azov-Dnieperian; i-Donetsian. 
ture are located in the valleys of middle courses of the rivers Dniester (Nistru), Southern Bug (Pyvdenyi Buh) and their tributaries.

Based on the occurrence of "hoe-like" bone implements and the impressions of cereals on the pottery, it was suggested (Danilenko 1969; Markevich 1974; Kotova 2002, 2003) that some kind of agriculture was practiced at these sites.

The pottery corpus includes deep bowls with an S-like profile and hemispherical flat-bottomed beakers made of clay tempered with organic matter and crushed shells. Ornamental patterns consist of rows of shell-rim impressions, finger impressions, and incised lines forming zigzags and volutes. Remarkably, several patterns find direct analogies in the "monochrome" pottery of the Balkan Early Neolithic (Starčevo-Criş culture). Imported potsherds of Linear Pottery (with "music-note" patterns) were found at the Soroki 5 site. The assessment of the coeval subsample yields $T=6193 \pm$ $205 \mathrm{BC}$ with $\sigma_{\mathrm{c}}=205$ (Figure 4d).

\section{Surskian}

The Surskian-type (S) sites were identified in the late 1920s in the Dnieper River valley upstream of the Rapids. To date, about 30 sites are known in that area and also in the Azov Sea coastal area and the lower stretches of the Seversky Donets River (Telegin 1996a,b). The small-sized sites are mostly found on river islets, sand dunes on the floodplain, and, rarely, on the slopes of river terraces. The pottery made of clay tempered with sand and crushed shells consists of conic vessels with S-shaped walls, decorated by rows of comb impressions and, rarely, incised lines. The oldest variety is essentially similar to that of Rakushechnyi Yar and Bug-Dniesterian. The estimation of the coeval subsample produced $T=5940 \pm 167 \mathrm{BC}$ with $\sigma_{\mathrm{c}}=167$ (Figure 4e).

\section{Dnieper-Donets Cultural Entity}

The sites belonging to the Dnieper-Donets (DD) culture are found in the middle and upper stretches of the Dnieper basin and that of the Seversky Donets River. More that 150 dwelling sites and about 20 cemeteries are known in northern Ukraine and southern Byelorussia (Telegin 1968, 1996a,b). Kotova (2002, 2003) distinguishes several "regional cultures": Volhynian, Kiev-Cherkassyan, Lisogubovian, and Donetsian. Telegin (1968, 1996a,b) includes in the DD also the Azov-Dnieperian, which Kotova $(2002,2003)$ considers as belonging to a separate "Mariupol cultural entity."

The main feature of the Dnieper-Donets (DD) culture is its pottery: thick-walled, conic or flat-bottomed (at its latest stages) vessels decorated by "comb-and-stroked" ornaments (Kotova 2002, 2003).

The subsistence of DD groups was essentially based on hunting and food collecting with freshwater fishing. There is evidence for stock-breeding, particularly in the southern areas. Domesticated species prevail in the animal remains of the Buz'ki site (Kiev-Cherkassyan culture); they are dominated by cattle (28\%), followed by sheep/goat (2\%), and pig (2.5\%). In a few cases, impressions of cultivated cereals have been identified on the pottery of the sites of the Kiev-Cherkassyan culture (Vita Litovskaya, near Kiev, Grini, Kamenka). The identified specimens belonged to hulled wheats (einkorn and emmer), hulled barley, oat, bitter vetch, and possibly peas (Kotova 2002).

The DD cultural area contains about 20 cemeteries, several of which have more than 100 graves. According to Kotova (2002), the Dereivka cemetery, which generally belongs to the KievCherkassy culture, includes burials that belong both to the Dnieper-Donets (longitudinal orientation) and Azov-Dnieperian (latitudinal) rites. The burials of the later stage of the same cemetery 
contain skeletons in the supine position having a longitudinal orientation. The burial inventory thus includes pottery belonging to the second stage of the Kiev-Cherkassyan culture. The ${ }^{14} \mathrm{C}$ measurements obtained for human bones from DD cemeteries have been processed with the use of "coeval subsamples" and yield $T=6601 \pm 209 \mathrm{BC}$ with $\sigma_{\mathrm{c}}=209$ (Figure 4f).

\section{Strumel-Gastyatin}

The Strumel-Gastyatin (SG)-type sites are considered (Telegin 1985) as belonging to the earliest stage of the Neolithic in Ukraine's forest-steppe. These sites are found on the Dnieper River in the vicinity of Kiev, either on the sand dunes of the floodplain, or on the slopes of the river terrace. The pottery, which consists of large conic vessels, was made of clay with an admixture of vegetable matter. The ornaments were formed by rows of comb impressions restricted to the upper part of the vessels.

In recent years, several ${ }^{14} \mathrm{C}$ dates have been obtained from measuring the organic matter from the pottery of several SG sites. Estimation of the coeval subsample yields $T=5819 \pm 160 \mathrm{BC}$ with $\sigma_{\mathrm{c}}=$ 128 (Figure 4g).

\section{Azov-Dnieperian Culture}

The Azov-Dnieperian (AD) sites are found in the valley of the Molochnaya River and in the Azov Sea coastal area. Nearly $90 \%$ of the animal remains from the Neolithic layers belong to domesticates, predominantly cattle, followed by horse, sheep, goat, and pig. The wild species include red deer, boar, and bison, with numerous remains of fish and birds. Pollen analysis performed by G A Pashkevich reveals vegetation of bunchgrass steppe with rare occurrence of trees (birch, alder, elm, and hornbeam).

Series of ${ }^{14} \mathrm{C}$ dates were obtained for several AD sites, including the corresponding layers of Semenovka, Kamennaya Mogila (settlement), Stril'chya Skelya, Yasinovatka I, Nikol'ski, and Dereivka cemeteries. These dates yield $T=5313 \pm 187 \mathrm{BC}$ with $\sigma_{\mathrm{c}}=187$ (Figure $4 \mathrm{~h}$ ).

\section{Donetsian Culture}

Sites of the Donetsian culture are located in the basin of the Seversky Donets River. Series of ${ }^{14} \mathrm{C}$ dates were obtained predominantly from the stratified settlement of Tuba 2. The coeval subsample of the dates show the age of $T=5045 \pm 199 \mathrm{BC}$ with $\sigma_{\mathrm{c}}=199$ (Figure 4i).

\section{DISCUSSION}

The classical theory views the European Neolithic as essentially resulting from the spread of farming from western Asia either via direct migrations or by absorption and acculturation of indigenous Mesolithic populations. In southeastern Europe, the earliest manifestations of agriculture are seen at about 8.6-7.5 kyr cal BC (Franchthi Cave). The next stages of the early Neolithic in central and northern Greece include Proto-Sesklo (6.5-6.0 kyr cal BC) and Sesklo (6.0-5.3 kyr cal BC). Further north, in the northern Balkan area and Middle Danube basin, several early farming cultures were recognized, including Karanovo I-II (6.1-5.8 kyr cal BC), Karanovo III (5.4-5.1 kyr cal BC), Karanovo IV (5.3-4.8 kyr cal BC), Starčevo-Körös-Criş (5.9-5.5 kyr cal BC), and Vinča (5.5-4.0 kyr cal BC). The expansion of early agriculture in central and western Europe took the form of the Linear Pottery culture spreading at about $5154 \pm 62 \mathrm{BC}$ with an average speed of 4-6 km/yr (Dolukhanov et al. 2005). The new evidence cited above indicates that early pottery-making developed in the forest-steppe areas of the East European Plain much earlier than the first farming communities appeared in southeastern Europe. 

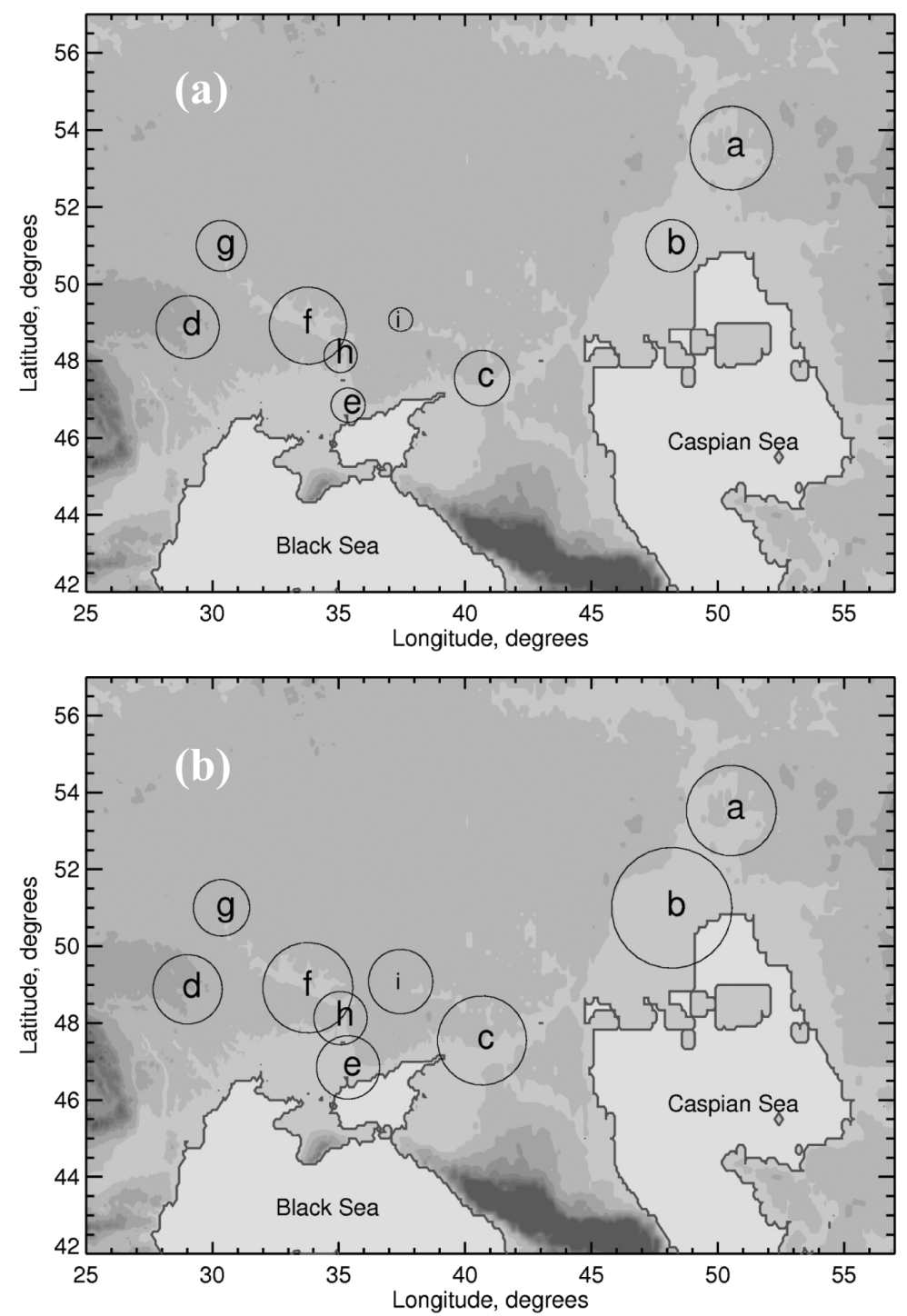

Figure 5 Geographic location and relative age of early pottery cultural entities in the south East European Plain. In panel (a), the size of the circle represents the coeval subsample date for each culture; in panel (b), the size of the circle represents the oldest date found for each culture. Larger circles indicate older dates. a-Yelshanian; b-North Caspian; c-Rakushechnyi Yar; d-Bug-Dniesterian; e-Surskian; f-Dnieper-Donetsian; g-Strumel-Gastyatin; h-Azov-Dnieperian; i-Donetsian.

The calculation of a coeval sample may be deemed as an instrument for assessing the most consistent settlement of a given territory (Figure 5a). On the other hand, older dates that usually lie beyond the coeval substantial are equally important, as an indication of the date of the earliest settlement (Figure $5 \mathrm{~b}$ ). Seen from this angle, our data are clearly indicative of a spread of pottery-making tradition from the east towards the west, apparently independently from the southeast European impulses. 
The earliest signals of pottery-making are apparent in the North Caspian area, the Middle-Lower Volga (Yelshanian, about 8-7 kyr cal BC), and the Lower Don (Rakushechnyi Yar; 7 kyr cal BC). Stable settlement, as indicated by the coeval subsamples, is evident in the Middle-Lower Volga (Yelshanian) at $6.8 \mathrm{kyr}$ cal BC, and in the Caspian Lowland and on the Lower Don at $\sim 6 \mathrm{kyr}$ cal BC. The age of the coeval subsample of Dnieper-Donets cemeteries is $\sim 6.6 \mathrm{kyr}$ cal BC. The age of Strumel-Gastyatin, Surskian, Dnieper-Donetsian, and Bug-Dniesterian sites lie in the time span between 6.2 and $5.0 \mathrm{kyr} \mathrm{BC}$. In the latter case, they overlap with the early farming entities (StarčevoKörös-Criş and Linear Pottery), whose influence is perceptible in archaeological materials. Remarkably, in all studied areas, the early Neolithic coincided with the optimal environments of the Atlantic period, which included a notable increase of rainfall, as seen in the ${ }^{14} \mathrm{C}$-dated pollen data.

The reported evidence confirm the previously formulated model (Davison et al. 2007), which suggests that the spread of the Neolithic involved at least 2 waves propagating from distinct centers. The western center stemming from the Near East, and the eastern one, spreading through the east via the "steppe corridor," resulting in the establishment of the "eastern version" of the Neolithic in Europe (Figure 1, white and black arrows).

\section{REFERENCES}

Belanovskaya TD. 1995. Iz drevneishego proshlogo Nizhnego Podon'ya: Poselenie vremeni neolita i eneitya Rakushechnyi Yar [From the Most Distant Past of the Lower Don Area: The Multilayered Neolithic and Eneoliothic Site of Rakushechnyi Yar]. St. Petersburg: St. Petersburg University Press. In Russian.

Bronk Ramsey C. 1995. Radiocarbon calibration and analysis of stratigraphy: the OxCal program. Radiocarbon 37(2):425-30.

Bronk Ramsey C. 2001. Development of the radiocarbon calibration program. Radiocarbon 43(2A):355-63.

Danilenko VN. 1969. Neolit Ukrainy [The Neolithic of the Ukraine]. Kiev: Naukova Dumka. In Russian.

Davison K, Dolukhanov PM, Sarson GR, Shukurov A, Zaitseva GI. 2007. A Pan-European model of the Neolithic. Documenta Praehistorica 34:139-54.

Davison K, Dolukhanov PM, Sarson GR, Shukurov A, Zaitseva GI. 2009. Multiple sources of the European Neolithic: mathematical modelling constrained by radiocarbon dates. Quaternary International 203(1-2): $10-8$.

Dolukhanov PM, Shukurov A, Gronenborn D, Timofeev VI, Zaitseva GI, Sokolof D. 2005. The chronology of Neolithic dispersal in Central and Eastern Europe. Journal of Archaeological Science 32(10): 1442-58.

Dolukhanov PM, Sarson GR, Shukurov A, editors. 2009. The East European Plain on the Eve of Agriculture. BAR International Series 1964. Oxford: Archaeopress. $246 \mathrm{p}$.

Gerasimenko NP. 1995. Holocene landscapes and climate changes in southeastern Ukraine. In: Climate and Environmental changes of East Europe during Holocene and Late-Middle Pleistocene. Moscow: Institute of Geography, Russian Academy of Sciences. p 38-49.

Khotinsky NA. 1977. Golocen severmoi Evrazii [The
Holocene of Northern Eurasia]. Moscow: Nauka. In Russian.

Khotinsky NA. 1987. Holocene climate change. In: Velichko VV, Wright Jr HE, Barnosky CW, editors. Late Quaternary Environments of the Soviet Union. Minneapolis: University of Minnesota Press. p 305-18.

Khotinsky NA, Klimanov VA. 2002. Rastitel'nost' golocena [The Holocene vegetation] In: Velichko AA, editor. Dinamika landshaftnyh komponentov $i$ vnutrennih morskih basseinov Severnoi Evrazii za poslednie 130000 let [Dynamics of landscape components and inner marine basins of Northern Eurasia over the Last 130,000 years]. Moscow: Geos. p 89-104.

Kotova NS. 2002. Neolitizatsiya Ukrainy [Neolithisation of Ukraine]. Lugansk: Shllyakh. In Russian.

Kotova NS. 2003. Neolithisation in Ukraine. BAR International Series 1109. Oxford: Archaeopress. 350 p.

Kremenetsky KV. 1991. Paleoekologiya drevneishikh zemledel'tsev I skotovodov Russkoi ravniny [Palaeoecology of Prehistoric Farmers and Stockbreeders of the Russian Plain]. Moscow: Nauka. In Russian.

Kremenetsky KV. 2003. Steppe and forest-steppe belt of Eurasia: Holocene environmental history. In: Levine M, Renfrew M, Boyle K, editors Prehistoric Steppe Adaptation and the Horse. Cambridge: McDonald Institute Monographs. p 11-27.

Lastovsky AA. 2006. Chekalino IV O kul'turnom statuse keramiki yelshanskogo tipe [On the cultural status of Yalshnian-type pottery]. In: Vasil'eva V, editor. Voprosy arheologii Povolzh'ya [The Problems of Archaeology in the Volga Area]. Issue 4. p 107-13. In Russian.

Lillie M, Budd C, Potekhina I, Hedges R. 2008. The radiocarbon reservoir effect: new evidence from the cemeteries of the middle and lower Dnieper basin, Ukraine. Journal of Archaeological Science 36(2): 
256-64.

Mamonov AE. 1994. Yelshanskii kompleks stoyanki Chekalino IV [The Yelshanian assemblage of Chekalino IV site]. In: Vasil'ev IB, editor. Drevnie kul'tury lesostepnogo Povolzh'ya [The Ancient Culture of the Forest-Steppe Transvolga Area]. Samara: Samara Pedagogical University Press. p 3-25. In Russian.

Markevich VI. 1974. Bugo-Dnestrovskaya kul'tura na territorii Moldavii [The Bug-Dniester Culture on the Territory of Moldavia]. Chişineu: Ştiinca. In Russian.

Pashkevich GA. 1982. Paleobotanicheskaya harakteristika poseleniya Mirnoe [Palaeobotanic characteristics of the Nirnoe site]. In: Stanko VN, editor. Mirnoe. Problema mezolita stepei Severnogo Prichernomorya [Mirnoe. The Problems of Mesolithic in the Northern Black Sea Area]. Kiev: Naukova Dumka. p 132-88. In Russian.

Reimer PJ, Baillie MGL, Bard E, Bayliss A, Beck JW, Bertrand CJH, Blackwell PG, Buck CE, Burr GS, Cutler KB, Damon PE, Edwards RL, Fairbanks RG, Friedrich M, Guilderson TP, Hogg AG, Hughen KA, Kromer B, McCormac G, Manning S, Bronk Ramsey C, Reimer RW, Remmele S, Southon JR, Stuiver M, Talamo S, Taylor FW, van der Plicht J, Weyhenmeyer CE. 2004. IntCal04 terrestrial radiocarbon age calibration, 0-26 cal kyr BP. Radiocarbon 46(3):1029-58.

Telegin DY. 1968. Dnipro-Donec'ka kul'tura [The Dnieper-Donets Culture]. Kiev: Naukova Dumka. In Ukrainian.

Telegin DY. 1985. Neolit [The Neolithic]. In: Artemenko II, editor. Arheologiya Ukrainskoi SSR [Archaeology of Ukrainian SSR]. Kiev: Naukova Dumka. In Russian.
Telegin DY. 1996a. Surskaya kul'tura [The Surian culture]. In: Oshibkina SV, editor. Neolit Severnoi Evrazii [The Neolithic of Northern Eurasia]. Moscow: Nauka. p 40-5. In Russian.

Telegin DY. 1996b. Dnepro-donetskaya kul'turnaya obshchnost' [The Dnieper-Donets culture entity]. In: Oshibkina SV, editor. Neolit Severnoi Evrazii [The Neolithic of Northern Eurasia]. Moscow: Nauka. p 48-65. In Russian.

Vasiliev IB, Panin GG. 1977. Yelshanskie stoyanki na reke Samare v Orenburgskoi oblasti [Yelshanian sites on the Samara River in Orenburg Oblast]. In: Neolit I brnzovyi vek Povolzhya i Priual'ya [The Neolithic and Bronze Age of the Volga and Cisuralian areas]. Kuibyshev: Kuibyshev Pedagogical Institute Memoirs. Volume 20. p 6-7. In Russian.

Vasiliev IB, Vybornov AA. 1988. Neolit Povolzh'ya. Step' i lesostep' [The Neolithic in the Volga Area. Steppe and Forest-Steppe]. Kuibyshev: Kuibyshev Pedagogical Institute Press. In Russian.

Volontir NN. 1989. K istorii rastitel'nosti yuga Moldavii $\mathrm{v}$ golocene [To the history of Moldavia's Holocene vegetation]. In: Quaternary Period. Palaeontology and Archaeology. Chişineu: Ştiinca. p 90-7. In Russian.

Yudin AI. 2004. Varfolomeyevskaya stoyanka i neolit stepnogo Povolzh'ya [Varfolomyevska site and the Neolithic of the Volga Steppe area]. Saratov: Saratov University Press. In Russian.

Zaitseva G, Skripkin V, Possnert G, Dolukhanov P, Vybornov A. 2009. Radiocarbon dating of Neolithic pottery. Radiocarbon, this issue. 